\title{
Market Concentration, Producer Organizations, and Policy Measures to Strengthen the Opportunities of Farmers for Value Addition-Empirical Findings from the Austrian Meat Supply Chain Using a Multi-Method Approach
}

\author{
Simon Pröll ${ }^{1, *(\mathbb{D})}$, Heidelinde Grüneis ${ }^{2}$ and Franz Sinabell ${ }^{3}$ \\ 1 Institute for Sustainable Economic Development, Department of Economics and Social Sciences, University of \\ Natural Resources and Life Sciences (BOKU), 1180 Vienna, Austria \\ 2 Federal Institute of Agricultural Economics, Rural and Mountain Research (BAB), 1030 Vienna, Austria; \\ heidelinde.grueneis@bab.gv.at \\ 3 Austrian Institute of Economic Research (WIFO), 1030 Vienna, Austria; franz.sinabell@wifo.ac.at \\ * Correspondence: simon.proell@boku.ac.at
}

check for updates

Citation: Pröll, S.; Grüneis, H.; Sinabell, F. Market Concentration, Producer Organizations, and Policy Measures to Strengthen the Opportunities of Farmers for Value Addition-Empirical Findings from the Austrian Meat Supply Chain Using a Multi-Method Approach. Sustainability 2022, 14, 2256. https:// doi.org/10.3390/su14042256

Academic Editors:

Konstadinos Mattas,

George Baourakis and Stefanos

A. Nastis

Received: 10 December 2021

Accepted: 10 February 2022

Published: 16 February 2022

Publisher's Note: MDPI stays neutral with regard to jurisdictional claims in published maps and institutional affiliations.

Copyright: (C) 2022 by the authors. Licensee MDPI, Basel, Switzerland This article is an open access article distributed under the terms and conditions of the Creative Commons Attribution (CC BY) license (https:// creativecommons.org/licenses/by/ $4.0 /)$.

\begin{abstract}
Improving market access and opportunities for value addition for small-scale food producers and family farms and properly functioning food commodity markets are among the objectives of the Sustainable Development Goals. Market structure and market concentration are important aspects that could make this goal attainable. In a case study, we explore the current conditions of pork and beef farmers in Austrian meat markets by combining a quantitative approach with qualitative inquiries. The quantitative analysis shows that the concentration of meat markets has been increasing in recent years. The rates of change differ in various segments of the value chain and across the types of markets. These results are the starting point for a qualitative analysis of the competitive situation in the observed markets. One finding is that in each market prices are set in idiosyncratic ways. Another one is that producer organizations are an appropriate means for small-scale and family-run farms to strengthen their position in the value chain. We conclude that policy initiatives to improve market access and value addition for farmers need to be complemented by targeted dissemination activities and that competition analyses should apply multi-method approaches similar to the one used in this analysis.
\end{abstract}

Keywords: market concentration; market power; meat industry; producer organizations; Austria; mixed methods approach; multi-method approach

JEL Classification: L11; L66; Q12; Q18

\section{Introduction}

Agricultural markets are typically characterized by a large number of sellers and a low number of buyers. In such situations, economic theory predicts farmers' prices being lower than those provided through a competitive market, as downstream firms are able to exercise buyer power [1]. Such firms may use their market position (monopsony power) to gain economic rents at the cost of producers, as recently exemplified in a study on the Irish beef market [2]. The undesirably lower quantity provided by the market creates welfare loss. Under certain conditions, consumers' welfare is further reduced by such forms of conduct [3]. In several sectors relating to agricultural products, the disparities existing between the number of producers and processors or retailers raise concerns regarding the abuse of a dominant market position. Producers of agricultural products, especially small farmers, are often perceived as a vulnerable and economically disadvantaged group of market participants [4]. 
Sustainable development goal (SDG) 2.3 addresses this situation, aiming to improve market access and opportunities for value addition for small-scale food producers and family farms; meanwhile, SDG 2.c aims "to ensure the proper functioning of food commodity markets" [5]. In line with these objectives, the most recent reform of the Common Agricultural Policy (CAP) of the EU aims to "improve the farmers' position in the value chains" by encouraging producer organizations (POs), promoting short supply chains, and supporting quality schemes (see Council document 2018/0216 from 23 July 2021). Apart from this, two recent legislative acts aim at contributing to a better functioning of food commodity markets: (1) Based on the Commission Implementing Regulation (EU) 2019/1746, the collection of statistical data necessary for the analysis of price formation mechanisms along the agricultural and food supply chain will be improved. (2) The Directive (EU) 2019/633 of the European Parliament and of the Council addresses imbalances in bargaining power between suppliers and buyers by defining and sanctioning unfair trading practices in business-tobusiness relationships in the agricultural and food supply chain. Due to how recently these were implemented, the effects of these regulations have not yet materialized; this may also be due to the fact that some member states have been reluctant to implement them in national legislation (in July 2021, the commission began infringement procedures against 12 Member States for not transposing EU rules banning unfair trading practices (details are available at: https:/ / ec.europa.eu/commission/presscorner/detail/en/IP_21_3903) (access on 18 November 2021). In this paper, we explore the relevance and implications of these goals by looking at Austria, which is among the EU Member States with many small farms [6]. Our analysis focuses on the beef and pork meat markets, as they make up $23 \%$ of agricultural outputs [7].

Traditionally, the CAP has supported POs in agriculture to overcome or at least reduce the asymmetries in food supply chains, and they will be supported in the coming period of the CAP strategic plan in a modified manner. A recent survey on this topic and empirical findings on the effects of support policies for POs in Slovakia were presented by Michalek et al. (2018) [8]. Austrian food producers have cooperated in POs for several decades; however, there is little empirical evidence regarding their impact on farmers' market position and the mechanisms through which POs enhance Austrian food producers' economic performance.

We attribute the lack of contributions to the complexity of capturing the manifold channels through which POs may change market outcomes and the lack of appropriate data. To address these shortcomings, our paper addresses quantitative aspects such as the concentration of meat markets through qualitative views from representatives of POs. Recent studies on POs have explored their roles in markets generally (e.g., Duvaleix-Treguer, 2018 for France) and/or their roles in the context of nationwide producer protests $[9,10]$. Our approach is - to our knowledge - the first one based on an EU meat market that combines quantitative and qualitative aspects in a multi-method approach to explore market concentration and its consequences for producers (a market is typically considered as concentrated if firms' market shares are distributed unequally. Market concentration, often used as a proxy for the intensity of competition, can accordingly be defined as the degree to which market measures are concentrated on a small number of firms [11]).

In line with SDG 2.3, the recent reform of the CAP aims to improve the conditions for the value addition of agricultural producers in the value chain. At present, however, there is only little evidence regarding market structure, market concentration, and their consequences for small-scale food producers. We explore market conditions in Austrian meat markets by combining a quantitative approach with qualitative inquiries. In this light, our aim is to contribute to the literature by evaluating the channels through which POs impact market participants' position in the industry and hereby gain further insights into the supply chain of meat markets at a time before the measures of the CAP strategic plan are put in place. In this paper, we evaluate the situation prior to the implementation of the regulations mentioned above and hereby provide a starting point for further research on the effectiveness of recently introduced instruments in strengthening the position of 
farmers in the value chain. We address the aim of our study by investigating four research topics, as described in the next paragraph.

Research topic (1) is to identify the change in the structure of market participants by measuring the market concentration of the Austrian meat supply chains over time on different levels. We use quantitative methods to do so. However, the available data from meat markets are not sufficient to describe or explain the forces that determine competition throughout the value chain. Research topic (2) is to explore the strategies and tactics employed by participants of Austrian meat markets-in particular, we are interested in the strategies of POs which allow small-scale farmers to strengthen their position in the market. It is necessary to gather this information from people working in these markets. Stakeholder and producer interviews, representing our qualitative approach, give us insight into the mechanisms of POs. In research topic (3), we are interested in the stakeholders' and producers' knowledge and perceptions regarding the relevance of newly implemented EU policy measures. In research topic (4), we aim to explore the benefits and limitations of the multi-method approach employed in this study. Our aim is, therefore, to show an example of how the policy objectives aiming to improve the functioning of food commodity markets and the opportunities for value addition for small-scale farmers can be analyzed by using established methods in social sciences. Our aim is to contribute to the corpus of literature that investigates alternative strategies for improving the economic condition of small-scale farmers by linking producers directly with consumers, similar to Krejčí et al. (2019), who used a system dynamics approach, and Lutz et al. (2017), who used a social multi-criteria evaluation approach $[12,13]$.

In the literature, market concentration serves as a proxy for market participants' position in the supply chain. Peleckis (2022) and Di Foggia and Beccarello (2021) investigate non-food markets in this tradition [14,15]. Nes et al. (2021) compared the concentration of EU food markets at several stages; however, the farm level was excluded [16]. In contrast to these studies and others, such as Fu et al. (2021), we evaluate market concentration at multiple stages of the supply chain [2]. Our research adds empirical evidence for a country with many small farms which are addressed in the SDGs and show how better insights can be obtained by complementing quantitative findings with information obtained by producer and stakeholder interviews.

This paper proceeds as follows: Section 2 gives a brief overview of the relevant literature. Section 3 describes the quantitative and qualitative methods and data used, while Section 4 provides results from descriptive data analyses and stakeholder interviews. In Section 5, we end with a short summary of the topics addressed in this paper and a discussion of our results concerning the specific SDGs addressed in this paper and the concept of sustainability in general.

\section{Literature}

In order to analyze market concentration, we based the roles of POs and the policy measures used to strengthen their position on findings detailed in the literature from various fields. To limit our scope, we concentrate on meat producers and meat markets. We start with a literature review focusing on studies on market power or a lack of competition in these markets and then widen our scope to address the complex relationships of firms in the value chain. According to our review, only a few studies deal with POs and meat markets. In the final part of this section, we present research that deals with the methodological approach taken in this study, which combines quantitative and qualitative methods. Our case study focuses on Austria. For this country, there are several studies analyzing market power and market concentration [3,17,18], and one that deals with meat markets [19], but there are no studies dealing with POs in meat markets.

In the literature, there are three major strands regarding market structure and (agricultural) producers along the supply chain that are not well integrated (throughout the text, we follow Carlton and Perloff (2015) in characterizing the type of market structure by: "The number of firms in a market and the ease of entry and exit by new firms [...]" [1] 
(p. 31)). In the first one, market structures and outcomes are viewed from an industrial organization perspective and analyzed accordingly by identifying the market and its structure, before using econometric techniques to measure the market power based on market observations benchmarked against an hypothetical efficient market outcome [20,21]. Most studies that have applied such methods to measure market power in meat markets are from the U.S. [22-25], while several studies are from other countries, such as Canada [26], Austria [19], Japan [27], Germany [28], and China [29]. The OECD (2006) provides empirical evidence for Canada, the Czech Republic, Japan, and the Netherlands [30].

Apart from the difficulties of single parameter estimation, the heterogeneity of distinctive agricultural sectors poses an additional challenge in estimation due to the necessity of accounting for all important details adequately. The level of organization of farmers, the differentiation and shelf life of products, and the structure of sales channels are decisive factors determining the market position of farmers and vary greatly depending on the sector and even market segment.

In the industrial organization literature, buyer power is defined as the distance between the observed price and the hypothetical price in a competitive market. In view of the complex supplier-buyer relationship along the food supply chain, such a simplification appears to be inadequate. An alternative framework that can be used to capture aspects of competition over the whole supply chain in a wider context was developed by Porter in the "competitive forces framework" from a business economics perspective, which is part of the second strand of the literature [31]. The relevant forces identified by Porter are: the threats of new entrants, the threat of substitute products or services, the bargaining power of suppliers, and the bargaining power of customers. In the third strand, a social science strand, the effects of farmer organizations are analyzed, either with a view to their effect on income (e.g., Michalek et al., 2018 or de Roest et al., 2018) or to their role in specific markets (e.g., Duvaleix-Treguer, 2018 for France or Javornicky et al., 2021, for a case study in Ireland) [8-10,32]; however, how POs effectively interact with buyers and how prices and supply relationships are determined is not yet well understood.

Quantitative approaches, which are predominantly applied in economics, can reach their limits when it comes to gaining insight into the level of competition. Apart from the major problem of data availability, econometric methods may suffer from model specification problems or selection issues. The estimation of market power as a single parameter, as is often the case in industrial economics, especially in New Empirical Industrial Economics (NEIO), is problematic if market power is determined by multiple factors that may be difficult to quantify [33].

In such environments, researchers need additional information gathered by qualitative methods to complement quantitative research. To evaluate the superiority of such a multimethod design over a single-method approach, Goerres and Prinz (2012) suggest checking their two necessary and six sufficient conditions [34].

Despite the potential of supporting quantitative methods with qualitative methods in industrial and agricultural economics, only a few journal articles are based on a multimethod approach. Interviews conducted by Lenger and Kruse (2017) reveal the strong skepticism of German economists regarding the validity of qualitative methods [35], and consequently qualitative empirical work is rarely found in German economic journals. Studies in which interviews are conducted mainly use these to collect primary data, which will be evaluated descriptively. Schlippenbach and Pavel (2011) use a survey on brand manufacturers in the food, non-food, and near-food sectors in Germany to evaluate buyers' power [36]. In a similar fashion, Wieser et al. (1999) investigate the Austrian food sector by surveying the food processors and purchasing managers of large food retailers [16].

The investigation of effect of the Austrian federal competition authority on retailers demonstrates the importance of the use of qualitative methods for evaluating market power in an industry where buyers' power can be multidimensional [3]. Making use of the obligations of retailers to make disclosures to competition authorities, they evaluate the unfair trading practices used by retailers to gain economic rent from their suppliers. In a 
second step, they assess the relevance of unfair trading practices regarding competition law. Even on a global scale, the number of studies applying a multi-method approach to an economic problem is limited. Hereby, Akimowicz et al. (2018) asses the use of mixed-methods research in agricultural economics and conclude that agricultural economists would benefit from the use of mixed methods [37], while Jefferson et al. (2014) emphasize the potential of mixed-methods studies to facilitate richer insights and a better understanding of causal relationships in their application to labor economics [38].

\section{Data and Methods}

To gain deeper knowledge of the channels through which POs impact Austrian farmers' market position and perceptions of policy measures' impacts, we make use of descriptive data analysis as our quantitative approach as well as stakeholder and producer interviews as our qualitative approach. We decided to conduct qualitative interviews because the quantitative data were not sufficient. We also wanted to collect information on sensitive issues (e.g., on price negotiations) and personal assessments (e.g., regarding policy measures). Our procedure was based on the following three steps. (1) We used quantitative analysis to gain information on market concentration. This provided a sector overview and revealed at which stages of the supply chain we would encounter the potential for strong market positions. (2) Based on a literature review, we identified factors that may allow POs to improve the position of meat producers in the supply chain and other important determinants of their market position. (3) We developed interview guidelines based on steps (1) and (2), which aimed at deepening the knowledge gained through the quantitative analysis and validating its results. In addition, we made use of stakeholder and producer interviews to obtain relevant knowledge on the organizational structures of agricultural markets (the organization of trade in Austrian agricultural markets is very heterogeneous across individual sectors and is partly characterized by long-lasting customs and trade patterns). The persons who were interviewed were informed about EU legislation banning unfair trading practices-in particular, a list of unfair trading practices (Directive (EU) 2019/633) was drawn up.

\subsection{Quantitative Method and Data}

To measure the market concentration, we calculated the four-firm concentration ratio (CR4) as the sum of the top four firms' market shares:

$$
C R 4=\sum_{i=1}^{4} s_{i}
$$

where:

$$
s_{i}=\frac{x_{i}}{\sum_{i=1}^{N} x_{i}} .
$$

This equation captures firm $i$ 's share in an industry's total of a variable of interest $x_{i}$-typically, sales. A high value hereby indicates a concentrated industry. CR4 is commonly used to summarize an industry's market structure-e.g., perfect competition or oligopsony [39]. In addition, we provide the Herfindahl-Hirschman index (HHI). In contrast to $C R 4$, the $H H I$ uses information on all firms in a given industry and its computation requires data on all individual firms' market shares. In computing the HHI, we followed the convention in the literature and used shares $s_{i}$ multiplied by 100 , which we denote as $\dot{s}_{i}$ :

$$
H H I=\sum_{i=1}^{N} \dot{s}_{i}^{2} .
$$

As our interest lies in measuring the concentration in the buyers' market, we aimed to use individual firms' shares in industry livestock demand to calculate the HHIs. As a proxy, we used individual firms' shares of processed animals in the industry's total of processed 
animals. A high value of $\mathrm{HHI}$ indicates a high market concentration and is either reached through there being a low number of firms in the market; a large heterogeneity of firms concerning the variable of interest-i.e., firms' demand for livestock; or both. HHI ranges from 0 to 10,000, where a value close to 0 indicates a perfectly competitive market while a value of 10,000 is reached by a monopsonist. Additionally, the thresholds of the $H H I$ levels are defined by the U.S. Department of Justice (2010): a market with an HHI value lower than 1500 is perceived as unconcentrated, one with an $\mathrm{HHI}$ value between 1500 and 2500 is referred to as "moderately concentrated", and markets with an HHI larger than 2500 are described as highly concentrated [40].

A theoretical connection between $\mathrm{HHI}$ and market power can be established; however, its usefulness is limited in empirical studies. A high $H H I$ value is not necessarily an indicator of high market power, although it can be a necessary condition for the latter. In the situation we observe, however, it is helpful to gain information about potential buyer power, which is why we consider the $H H I$ as a suitable indicator for our purposes.

We drew our data on the number of cattle from the cattle database provided by the Agricultural Marketing Board Austria (AMA). The dataset covers all cattle produced on Austrian farms [41]. The number of pigs was based on a random sample drawn from all Austrian pig farmers [42] (the legal basis for collecting the data is EU regulation $1165 / 2008$ and the corresponding national regulations (BGBl. II Nr. 163/2012 and ViehMeldeverordnung 2018)). We observed the number of live pigs and cattle over the years from 2010 to 2020. To calculate HHIs at the level of meat processing, we used data from slaughterhouses processing more than 6000 cattle, 2500 calves, or 50,000 pigs from 2010 to 2020 .

\subsection{Qualitative Data and Methods}

We conducted semi-structured interviews with stakeholders and producers in the beef and pork markets, allowing for targeted questioning as well as follow-up questions on sensitive topics, such as market concentration. We developed guidelines (see Appendix A) leading through the conversation, ensuring that all topics were covered while leaving enough room for new issues to arise. In total, 20 interviews were conducted from May to September 2021. A protocol was made for each interview.

Our ten interview partners represent different groups in the supply chain for beef and pork meat markets in Austria (farmers, slaughterhouses, food retailers, and wholesalers). The main topics in stakeholder interviews were selected based on the literature research. Each topic represented a main driver of market participants' positions, which are described in the next paragraph. From the stakeholder's perspective, the four topics we evaluated were strongly interrelated. Interview guidelines (in Appendix A) were designed to transfer stakeholders' knowledge and their assessment of the situation in the Austrian meat market to answer our research questions.

POs allow farmers to concentrate their supply, increase bargaining power in trading with buyers, and hereby improve their market position [43-45]. Moreover, POs can impact market participants' position in the supply chain indirectly through representatively conducting price negotiations for farmers, setting up contracts, or designing quality programs.

Pricing and contracts: Although agricultural products are often assumed to be traded on spot markets, it is not entirely clear how prices are set $[4,46]$. Understanding the mechanism of price setting is therefore crucial in order to understand market participants position in the supply chain. As buyers could possibly exert bargaining power through setting favorable conditions in contracts with producers, we decided to ask stakeholders about practices in the industry.

Quality programs for retailers are a form of vertical integration that offers participating farmers a price premium and planning security. Through a locked-in relationship, farmers are, however, more vulnerable to unfair trading practices and lack other sales opportunities $[4,46,47]$. 
Finally, we aim to evaluate how the stakeholders of our sample perceived the usefulness of policy efforts aimed at strengthening the position of farmers in the food supply chain [44].

To complement our findings, 10 agricultural producers were interviewed in person about farm structures, costs, marketing, contract conditions, and policy strategies to illustrate the suppliers' situation (interview guideline is in Appendix B). Transcripts were prepared for all interviews serving as a basis for the qualitative content analysis [48]. Within this process, we coded all statements that could be assigned to one of the above-mentioned topics.

\section{Results}

\subsection{Quantitative Results}

In the upstream market of cattle farmers, $\mathrm{HHI}$ values for live cattle (all cattle categories) were between 0.29 in 2010 and 0.40 in 2020. Considering that the HHI is bounded between 0 and 10,000, we faced a very competitive market. These values are a result of a large number of cattle farmers with similarly small market shares. Based on a very small initial value, the $H H I$ increased by approximately $40 \%$ between 2010 and 2020. Analyzing the market concentration for 14 subcategories mainly based on the age and sex of cattle, we similarly observed rising concentrations in most cases. We found some higher $\mathrm{HHI}$ values for individual subcategories. Due to the lower number of farms, small submarkets-i.e., for calves-already have potential for a high market concentration due to the lack of competitors. In addition, we found very different results regarding magnitude in $\mathrm{HHI}$ for distinctive subcategories. For the year 2020, we hereby calculated a maximum value of $\mathrm{HHI}$ of 833 in the market for cows between 1.5 and 2 years.

In the downstream industry of meat processors, HHIs were calculated using data on the quantities of live cattle and pigs processed. In addition, we observed the quantities processed according to their meat categories. We calculated HHI values of between 1538 in 2010 and 1648 in 2020 for the aggregated meat category of grown cattle, which solely excludes calves. The magnitude of the calculated HHI suggests a moderately concentrated market. In the following, the market concentration is considerably higher than in the upstream market of cattle farmers. Figure 1 depicts an overall increase in the $\mathrm{HHI}$ within all categories of slaughtered bovine animals but bulls, which is accompanied by fluctuations in market concentration over the observation period (we observed the following six meat categories for beef: young bulls, bulls, bullocks, cows, heifers, and calves. Similarly, we observed two meat categories for pork: pigs and sows. The aggregate category of grown cattle consisted of the first five categories listed). In both categories for pork (pigs and sows), we observed an increase in market concentration of $42 \%$ and $22 \%$, respectively, between 2010 and 2020.

Our dataset allowed us to distinguish between animals raised in Austria and animals with other origins. Imports only accounted for a small fraction of slaughtered cattle and thereafter the magnitude of $H H I$ calculated for the entire market and for the Austrian cattle market was within a similar magnitude, with an annual average of 1577. The market concentration for imported livestock was found to be substantially higher, as only a small number of Austrian slaughterhouses import livestock. The mean value of $H H I$ over the observation period from 2010 to 2020 was above 2500, indicating a highly concentrated market. The development of market concentration was similar to that of the entire market, however at a higher level.

Table 1 gives further information on the structure of beef and pork livestock markets. Column 1 shows two types of slaughterhouses, whereas type I captures the total number of firms operating in 2018 in the production of meat and meat products, as classified by the ÖNACE-Code C101 [49]. The number of type II slaughterhouses that are considered to be systemically relevant firms is described in Section 2 . The number of slaughterhouses reveals that the majority of animals are slaughtered by a small number of type II firms, while there are a large number of small, possibly family-owned, meat producers classified as type I 
slaughterhouses. As a widely used measure of market concentration, we included the concentration ratio of the four largest meat processors in 2020. Typically, a high correlation between $H H I$ and $C R 4$ was found. Our results show the same pattern.

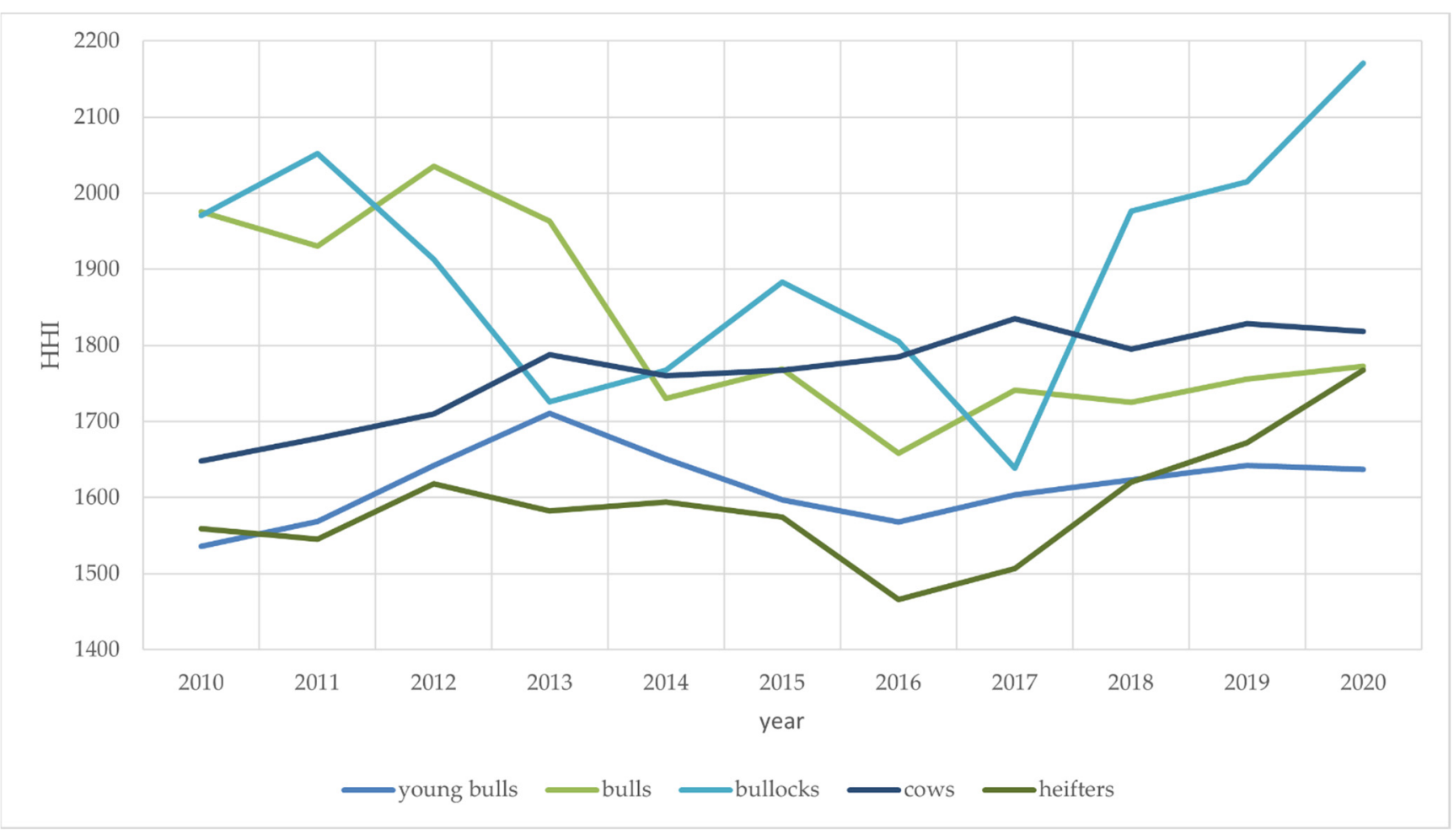

Figure 1. HHI of Austrian meat processors by meat category.

Table 1. Descriptive statistics for Austrian beef and pork supply chains.

\begin{tabular}{|c|c|c|}
\hline $\begin{array}{c}\text { Upstream Market (UM)/Downstream } \\
\text { Market (DM) }\end{array}$ & $\begin{array}{l}\text { Number of Firms in UM/Number of Firms } \\
\text { in DM }\end{array}$ & $H H I, C R 4$ in $\mathrm{DM}^{1}$ \\
\hline Pork producers/slaughterhouses & $\begin{array}{ll}\text { - } & \text { farms: } 21,092 \\
\text { - } & \text { slaughterhouses type I: } 876 \\
\text { - } & \text { slaughterhouses type II: } 14\end{array}$ & $\begin{array}{l}\text { HHI pigs: } 1470 \\
\text { CR4 pigs: } 0.70\end{array}$ \\
\hline Beef producers/slaughterhouses & $\begin{array}{ll}\text { - } & \text { cattle farms: } 56,389 \\
\text { - } & \text { slaughterhouses type I: } 876 \\
\text { - } & \text { slaughterhouses type II: } 12\end{array}$ & $\begin{array}{l}\text { HHI grown cattle: } 1648 \\
\text { CR4 grown cattle: } 0.76\end{array}$ \\
\hline \multicolumn{3}{|c|}{$\begin{array}{l}\text { Data sources: Type I: Total number of firms being considered as meat processors and preservers within Austria } \\
\text { in } 2018 \text { according to the Austrian industry classification. Relevant firms fall under the ÖNACE code C101 [49]. } \\
\text { Type II: Data source of type II firms is described in the section "data and methods". Values reported were } \\
\text { collected in year 2020. Number of firms obliged to report data can only be seen as an approximation, as data } \\
\text { collection was subject to several uncertainties. }{ }^{1} \text { For type II slaughterhouses, calculated indices are based on } \\
\text { purchasing quantity. }\end{array}$} \\
\hline
\end{tabular}

The lack of data available for the quantities of meat and meat products purchased by retailers impedes the evaluation of market concentration at the wholesale level. Table 2 shows that the top four Austrian retailers' revenues from meat accounted for more than $90 \%$ of the total industry revenues in 2020. Austria's top four retailers were hereby able to increase their market share in terms of industry revenue by more than $3 \%$ for meat and more than 5\% within the category of ham and sausages between 2014 and 2020. 
Table 2. Market concentration of retailers in the Austrian meat market.

\begin{tabular}{ccc}
\hline & CR4 2020 & 1 \\
\hline Meat & 0.95 & $+3.75 \%$ \\
Sausages and ham & 0.93 & $+5.12 \%$ \\
\hline
\end{tabular}

Data source: [50]. ${ }^{1}$ CR4 calculation is based on retailers' sales.

Overall, we found a low concentration in the upstream market for live cattle, with differing magnitudes of $\mathrm{HHI}$ for individual meat categories and over time. Except for Finland, which can be perceived as an outlier in the market concentration for most foodand beverage-producing sectors, Nes et al. (2021) found similarly unconcentrated meat manufacturing markets in several other EU member states (Bulgaria, Czechia, Spain, France, Italy, Hungary, Portugal, Romania, Finland, and Sweden) [15]. A substantially higher market concentration was observed in the downstream market of slaughterhouses. An increase in market concentration was found in all individual meat categories, except for bull meat. The consumer market for meat and meat products was found to be highly concentrated.

\subsection{Qualitative Results: Interviews}

In this chapter, we present the results of the qualitative interviews. All information provided within this section comes from our interview partners. Based on 20 interviews with stakeholders and agricultural producers operating in the beef and pork markets, we try to gain deeper insight into the topics presented in Section 3.2: POs, pricing, contracts, quality programs, and political strategies.

\subsubsection{Producer Organizations}

The first thematic block of our interviews concerns the POs of meat producers, which have shown strong growth within the last 20 years. Currently, about one-third of producers are members of a PO (beef: 30-35\%; pig: approx. 35\%). These organizations are, among others, promoted by the EU in order to improve supply and marketing structures and thus competitiveness. Members pay fees or commissions and, in return, receive a wide range of services, such as advice, feed procurement, young animal procurement, or joint marketing. As a further service, POs represent their members externally-e.g., in certain committees with the Chamber of Agriculture or the Federal Ministry of Agriculture, Regions, and Tourism (BMLRT). At such occasions, current issues and the orientation of the market are discussed. Beef and pork producers can participate in meetings and pass on their concerns to the POs. Although the representatives of POs would like to increase their market share to strengthen their position, the representatives of slaughterhouses interviewed considered the current composition of POs and livestock traders to be balanced. This leads to "healthy competition", and producers felt they had sufficient freedom of choice regarding marketing. While members of POs had more planning security for sales and prices (price guarantee, purchase guarantee, payment guarantee), producers who sell directly or through livestock traders had more autonomy and speculation possibilities. Livestock traders were therefore competitors of POs, and often had long-standing business relationships with producers. Direct marketers were also competing with POs. Interviewed producers with direct marketing reported that they could act more autonomously and flexibly. From the perspective of $\mathrm{PO}$ representatives, producers who are not members of a $\mathrm{PO}$ are free riders, as the efforts of POs, especially in price negotiations, would benefit all producers in the market. However, one producer expressed concerns that the cooperation between POs and large trading companies would lead to a strong concentration of power. POs were usually heavily involved in the development of long-term quality programs, as such efforts require a great deal of planning and organizational capacity. 


\subsubsection{Pricing and Contracts}

Prices are primarily negotiated between POs, slaughterhouses, and food traders. Producers cannot negotiate prices directly with retailers. Beef and pork farmers who are not members of a PO sometimes sell directly to slaughterhouses or to livestock traders, who in turn negotiate with slaughterhouses. Directly marketing farms can set their prices autonomously; however, they are also dependent on market conditions.

The producer price for beef is negotiated weekly by "ARGE Rind", the umbrella organization for producer and interest groups for beef production, with the five largest slaughterhouses. Separate prices are set for different categories and quality labels with surcharges and discounts. In addition to supply and demand, international prices are considered during price setting. The resulting prices also form the basis for negotiations between slaughterhouses and retailers. Overall, prices are described as relatively stable, with slight seasonal fluctuations. As a more recent development, agreements with contracts are made with producers in special quality programs.

The prices for pork are very volatile and are similarly negotiated weekly between slaughterhouses and the Austrian Pig Exchange (Österreichische Schweinebörse). Supply and demand as well as the international market are taken into account. Although the price is, in principle, only valid for PO members, it is adopted by the industry. Prices between slaughterhouses and trade are negotiated on the basis of the quotation, as in the cattle sector.

In principle, several actors reported on negotiations between POs and slaughterhouses on an equal footing; contractual relations with retailers were sometimes seen as more difficult. In food retailing, the top three retailers' market share accounted for $80 \%$. According to several interviewees, retailers "abuse" their dominant market position, which "makes the situation very difficult". From the point of view of a food retailer representative, however, retailers' share of the total food demand is not large. In addition, the interviewee mentioned increased feed costs currently causing conflicts; however, they stressed that POs were the ones who set prices. According to another food retailer representative, there was great effort to maintain stable, cooperative relations with food producers.

\subsubsection{Quality Programs}

Quality programs are mainly driven by animal welfare and sustainability aspects and are of increasing importance within society. In the cattle sector, regional programs are also offered. Especially for new farm managers, such programs can have a motivating effect, as they allow farmers to bring their strategies in line with societal demands. According to all interviewees, quality programs have become more important in recent years as quality meat can be marketed particularly well. One interviewee from a slaughter and processing company estimated the number of different programs in the cattle sector to be 70. In 2019, $75 \%$ of all slaughtered cattle were produced within a quality program, with even further expansion expected by a representative of a food retailer.

Austria's most important quality program is the EU co-funded AMA quality label, which requires, among other things, compliance with rules of origin. The share of organic meat is found to be increasingly important and growing steadily; accordingly, quality programs focusing on organic production are becoming increasingly important. In the organic pork sector, one representative of a food retailer even reported facing problems meeting a sharp rise in demand. In addition, several other quality programs initiated by different food retailers exist.

Quality programs typically have specific contract conditions-e.g., one-, five-, and tenyear contracts for certain animal welfare programs. POs often play a significant role in their design, as a great deal of consultation and coordination with numerous actors is needed to develop, establish, and run such programs. However, not all farms are able to participate in such programs; in the cattle sector, for example, there are waiting lists, whereas in certain regional programs suppliers are actively sought after. In order to be accepted into quality programs, producers have to fulfill higher quality criteria than are required by 
law-e.g., regarding feeding or husbandry requirements, which are regularly controlled. For programs in the cattle sector, producers have contracts with the inspection bodies and programs; in addition, there is a supply agreement with conditions to be met. The animals to be delivered are registered for a whole year, and a bonus is paid if the criteria are met. Overall, several respondents among the producers were critical in quality programs.

\subsubsection{Political Strategies}

The interviewees from the first round of interviews were asked about their opinion on the EU Task Force on Agricultural Markets and the Austrian market transparency regulation. The majority of the interviewees were not familiar with these strategies, and if they were their opinions were mostly negative-e.g., they stated they were "useless", "not the philosopher's stone", "nonsensical". One interviewee said that more transparency is always important, but that comparability is hardly given because the categories of the Market Transparency Regulation are too broad. Some interviewees said that prices were more transparent than ever and that the regulation would only lead to more bureaucracy. Among the producers interviewed, the market transparency regulation was largely unknown.

\subsection{Implications for Sustainability}

One reason why the SDGs of the UN have had a high impact on public awareness is that the objectives are defined in such a way that their attainment can be observed using relatively easy-to-measure indicators. For the two goals of interest in this paper, 2.3 (improving market access and opportunities for value addition for small-scale food producers and family farms) and 2.c (the adoption of measures to ensure the proper functioning of food commodity markets to help limit extreme food price volatility), the indicators are the volume of production per labor unit per size class of enterprises and indicators of food price anomalies. The first set of indicators is reported in the regular farm income reports of many countries (e.g., European Commission, 2021 for the EU [51]; BMLRT, 2020 for Austria [52]), while the second can be measured by standard indicators such as the log standard deviation or the coefficient of variation of price time series [53,54].

Our results showed that the Herfindahl-Hirschman index (HHI) is well suited to identifying the market structure in a given value chain by measuring the concentration at each stage of the value chain. We also showed that, by comparing HHIs at various stages of the value chain at different points in time, the development of structural change can be observed in quantitative terms. Even while the concentration of supplies offered by farmers increased over time due to structural change, the levels of concentration are much smaller at the farm level compared to the level of processors. Compared to food retailers, the concentration in the processed meat market is also much smaller. A high concentration in food markets may imply higher prices for consumers due to lower supplies of food and therefore conflict with SDG 2, which aims, among other things, to end hunger, achieve food security, and improve nutrition. In order to address these aspects, it seems to be worthwhile to broaden the scope of the indicators of SDGs as defined by the UN (2017) by including some measure of market concentration, as demonstrated in this study, as an additional indicator [5].

The topic of this study is small-scale farmers and the functioning of markets, with a focus on meat markets. Meat is an important source of protein and therefore essential to reduce hunger (SDG 2), particularly in pastoral societies (addressed in SDG 2.3). However, meat production - in particular, meat produced with inputs that could otherwise be used for human nutrition-is associated with emissions of greenhouse gasses (Bellarby et al. 2013) that could be avoided if consumers switched to plant-based nutrition (Chai et al., 2018) $[55,56]$.

\section{Concluding Remarks}

In research topic (1), we carried out an analysis of market concentration segment by segment along the vertical chain in beef and pork markets in Austria for the first time. The 
data showed a very competitive market at the producer level and a high concentration in retail markets. This finding is not new but, based on our analysis, we showed that the dynamics vary between markets and across different levels of the value chain. At the level of meat processors, we found a growing market concentration within all categories of slaughtered bovine animals but a decreasing market concentration for bulls. The market concentration (measured in HHI values) for imported livestock was found to be substantially higher than that for Austrian livestock. We calculated the HHI values to be close to zero (competitive market) at the producer level. Additionally, the processors' market could be characterized as moderately concentrated, with HHI values between 1538 in 2010 and 1648 in 2020 and with an CR4 of more than 0.9. Finally, the retail sector was found to be highly concentrated. We found that indicators such as $\mathrm{HHI}$ and CR4 are well suited to complement the indicators of the sustainable development goals that are listed by the UN (2017) because information on the market structure may shed light on the viability of small farms and the potential limitations of supplies of food in the market.

Our research topic (2) aimed to explore the strategies and tactics employed by the participants of Austrian meat markets to strengthen their position in their market. Producer organizations (POs) have to provide tangible and valuable services for their members, who would otherwise become involved in direct sales with consumers or sell their products to independent dealers or directly to processors. Based on stakeholder and producer interviews, we found that participating in a PO is advantageous for many producers because supplies are aggregated, which makes price setting more transparent. Pos also seem to be able to exert some negotiating power in price setting. To limit market disturbances by foreign entrants, producers developed certificates of origin. Quality schemes impose additional costs and their benefits depend on idiosyncratic conditions. The assessment of competing labels showed the tactics of market participants used to deal with threats posed by substitute products or services. In research topic (3), we explored stakeholders' and producers' knowledge and perceptions regarding the relevance of newly implemented EU policy measures. Our finding is that the persons interviewed were not well informed about these initiatives and skeptical about their potential benefits.

Finally, in research topic (4), we were interested in exploring the benefits and limitations of the multi-method approach employed in this study. Our descriptive results revealed a moderate market concentration in the buyers' market for live cattle and pigs. This is in line with qualitative findings from stakeholders, who confirmed that prices were strongly dependent on market forces. Stakeholder and producer interviews revealed the difficulties of food producers due to rising feed and investment costs, suggesting the existence of buyer power in downstream markets.

The market situation in Austria has many similarities to that of meat markets in other high-income countries. However, how the dynamics of market concentrations are similar could not be assessed due to the lack of similar analyses. Discussing our results in the context of the broad literature, we wanted to focus on the mixed-method approach employed in this study. For our research goals, such an approach has several benefits: (a) it helps us to understand the underlying processes that lead to market outcomes that can be observed in quantitative terms, such as changes in the levels of concentration; (b) it is necessary to gain insight into the price setting processes used and the details of contracts that need to be known when adequate industrial organization models are designed for econometric analyses of market power; and (c) such approaches will be necessary to evaluate the effects of complex policy interventions, such as those underway right now that aim to make new data obtained at several stages of the value chain available and strengthen the positions of producers who are exposed to unfair trading practices.

Finally, regarding the outlook and avenues for future research, we think that all stages of the agricultural and food value chains should be analyzed in a similar manner to explore the dynamics of market concentration. In Austria, quantitative information on the market between slaughterhouses and retailers is not available yet. The same is true for many other markets, such as fruits and vegetables and most arable crops. This deficiency will make it 
harder to assess the effectiveness of policies implemented to strengthen the market position of farmers. Exploring the prevalence of this observation in other EU Member States is probably a first step toward evaluating the benefits of such initiatives in the EU.

Despite the important tasks of POs, a large share of farmers are not members but rather have long-term business relationships with livestock traders or rely on direct marketing channels. Our results do not provide much information on farmers' incentives to choose certain sales channels. In order to foster competition in agricultural markets, one might conclude that CAP (Common Agricultural Policy) interventions to promote POs should not supersede alternative channels of marketing. We consider addressing this question as an interesting avenue for further research.

Our interviews with stakeholders about the value of recent policy initiatives to strengthen the market position of farmers showed mixed results, effectively demonstrating that the stakeholders' level of enthusiasm is underwhelming. Whether this finding is due to their lack of knowledge about the details of the new regulations or due to specific insights into the specificities of this market needs further exploration.

The multi-method approach used in this study was challenging for the whole research team. Those with expertise in qualitative methods and agri-sociology had no expertise in competition policies, market regulations, and unfair trading practices. Those with expertise in competition policy and quantitative market analysis were not very familiar with the idiosyncratic situations of each market and the various motives of market participants, which were broader than simply maximizing their profits. In order to assess the effectiveness of policies aiming to improve the position of famers in the value chain, it will therefore be necessary to establish discussion and cooperation formats for researchers from different disciplines in social sciences to build up the necessary research capacities. We conclude that multi-method approaches such as the one presented in our paper seem to be a promising avenue to tackle hard problems, such as those analyzing the trade-offs between different sustainability objectives, such as income inequality and economic growth. This brings us to one of the limitations of the approaches presented in this paper, whose advancements, when viewed from the angle of just one discipline, may seem mediocre.

This paper addressed sustainability by focusing on the Sustainable Development Goal 2 (SDG2: end hunger, achieve food security, improve nutrition, and promote sustainable agriculture), particularly on 2.3 (options for small-scale food producers) and 2.c (the proper functioning of food commodity markets). We found that the indicators used for measuring their attainment could be improved by including measures of market concentration, such as the Herfindahl-Hirschman Index or the market share of the biggest four companies in a market (CR4). However, such indexes only relate to the market structure and, therefore, are welfare-oriented in the sense of the incomes of small-scale farms or food expenditures for consumers. Welfare in a wider sense, which must consider the greenhouse gas emissions of meat production and consumption (addressed in SDG 13-take urgent action to combat climate change and its impacts), needs to be addressed in future research examining how to mitigate the trade-offs between different SDGs.

Author Contributions: Conceptualization, S.P., H.G. and F.S.; Funding acquisition, F.S.; Investigation, H.G.; Methodology, S.P. and H.G.; Resources, F.S.; Visualization, S.P.; Writing-original draft, S.P., H.G. and F.S.; Writing-review \& editing, S.P., H.G. and F.S. All authors have read and agreed to the published version of the manuscript.

Funding: This research was funded by the Austrian Federal Ministry of Agriculture, Regions and Tourism (BMLRT), research project $\mathrm{N}^{\circ} 101598$.

Institutional Review Board Statement: Ethical review and approval were waived for this study, due to application of the European General Data Protection Regulation (EU) 2016/679.

Informed Consent Statement: Informed consent was obtained from all subjects involved in the study. 
Data Availability Statement: The data used for this paper are from the Federal Institute of Agricultural Economics, Rural and Mountain Research (BAB). It collects, analyses, and makes available statistics on agriculture and the rural economy in Austria. Public data sets are available at: http:/ /bab.gv.at (accessed on 5 October 2021).

Acknowledgments: The authors thank Siegbert Linder and Dietmar Weinberger for efficient research assistance. The authors also acknowledge support by Lisa Eller, Lisa Bauchinger, Elisabeth Loibl, Philipp Schmidt-Dengler, Christoph Tribl, and Klaus Salhofer. Valuable comments and proposals of three anonymous referees helped to improve the manuscript significantly.

Conflicts of Interest: The authors declare no conflict of interest.

\section{Appendix A. Interview Guideline 1}

For interviews with representatives of interest groups, slaughterhouses, food retailers and wholesalers in the beef and pig market.

1. Introduction and market description

1.1 Please briefly describe your role in your organization.

1.2 What role does your organization have in the Austrian meat market?

1.3 How would you describe the meat market currently? Which were the most important developments within the last 10 years?

1.4 What are your expectations regarding future developments?

2. Costs and pricing

2.1 How have costs and prices changed in the last 10 years?

2.2 What is the composition of the cost structure of cattle and pig producers?

2.3 Would you advise producers to invest currently?

3. Contracts

3.1 How do contract actions take place on the meat market?

3.2 What role do the various players play in this process?

- With whom do producers negotiate the contracts?

- Who negotiates with the slaughterhouses?

- Who are the contract partners?

3.3 How long do such contractual relationships last on average and what does that depend on?

3.4 How has the design of contracts changed over the last 10 years?

3.5 How can suppliers or purchasers influence contract conditions?

4. Producer organizations

4.1 What role do producer organizations play in pricing or contract negotiations?

4.2 What advantages do livestock farmers have as members of a producer organization?

4.3 What are the disadvantages (especially in terms of prices and costs)?

4.4 What consequences arise when a livestock farmer changes buyers?

4.5 What role do product differentiations (organic, quality labels, quality programs) play?

5. Competition and foreign trade

5.1 How do you assess the current competitive situation on the market?

- Which market participants are there and what are their positions?

- What role do imports play and how do they influence the Austrian market?

- How do you assess the relationship between the individual players in this respect?

5.2 How has the situation changed over the last 10 years?

5.3 What role do exports play for the market? 


\section{Strategies}

There are some efforts to make the food market more balanced, e.g., at EU level, the Task Force "Agricultural Markets" (support of producer groups, more transparency, price information) or the Agricultural Market Transparency Regulation for Austria, which came into force on 1.1.2021 (reporting obligations for prices and quantities of agricultural goods and processed products).

How familiar are you with these strategies?

7. Closing

7.1 Do you believe that these are suitable and sufficient to improve the situation on the market as a whole?

7.2 What do you think is missing from these strategies?

We have now talked a lot about the current situation and strategies at EU and national level.

7.3 What do you think would be appropriate next steps or concrete measures to support fair competition in the market?

Thank you very much for your time. It helps us a lot to get a more complete picture for the meat market!

\section{Appendix B. Interview Guideline 2}

For interviews with agricultural producers in the beef and pig market.

1. Introduction and market description

1.1 Please briefly introduce yourself and your company.

1.2 Have there been any major changes on your farm in the last 10 years?

1.3 How would you describe the meat market currently? Which were the most important developments within the last 10 years?

1.4 What are your expectations regarding future developments?

2. Costs and pricing

If we now look at the economic side, ...

2.1 How have costs and prices changed over the last 10 years?

2.2 What is the composition of your operating costs?

2.3 Are you currently planning investments?

Producer organizations/Marketing

You have told that you produce...

2.4 How do you market your products? (POs?)2.5 Why are you (not) a member of a producer organization?

- If NOT: Have you ever been a member? Why did you drop out?

- If YES: What advantages do livestock farmers have as members of a producer organization? What are the disadvantages (especially in terms of prices and costs)?

2.5 Direct Marketers:

- Since when have you been marketing directly? What was before that? Why did you switch?

- How autonomous are you with pricing? How satisfied are you with it?

3. Contracts

I would like to know more about the terms and conditions with your contractors.

3.1 Who do you contract with and how do negotiations proceed?

Do you negotiate directly with customers? Do POs negotiate with customers?

3.2 How does a price come about? Can you influence it? 
3.3 What is the average duration of such contractual relationships and what does it depend on?

3.4 How satisfied are you with the contract conditions?

- The topic of unfair trade practices is a constant source of debate. How do you deal with it?How has the design of contracts changed over the last 10 years?

4. Strategies

In Austria, the Agricultural Market Transparency Regulation came into force on 1 January 2021.

4.1 How familiar are you with this strategy?

4.2 Do you believe that these are suitable and sufficient to improve the situation on the market as a whole?

4.3 What would you like to see in a strategy to strengthen the market position of farmers?

4.4 What do you think would be appropriate next steps or concrete measures to support fair competition in the market?

\section{Closing}

Thank you very much for taking your time. Your experiences are very valuable for us and we will gladly consider them in our project!

\section{References}

1. Carlton, D.W.; Perloff, J.M. Modern Industrial Organization, Global Edition, 4th ed.; Pearson Education Limited: London, UK, 2015.

2. Fu, R.; Li, C.; Wang, L. Market Power in the Irish Beef Processing Industry. Sustainability 2021, 13, 6453. [CrossRef]

3. Bundeswettbewerbsbehörde. Allgemeine Untersuchung des Österreichischen Lebensmittelhandels unter Besonderer Berücksichtigung des Aspekts der Nachfragemacht; Bundeswettbewerbsbehörde: Vienna, Austria, 2007.

4. Sexton, R.J.; Xia, T. Increasing Concentration in the Agricultural Supply Chain: Implications for Market Power and Sector Performance. Anпu. Rev. Resour. Econ. 2018, 10, 229-251. [CrossRef]

5. UN General Assembly. Resolution 71/313: Work of the Statistical Commission Pertaining to the 2030 Agenda for Sustainable Development, A/RES/71/313 (2017). Available online: https://undocs.org/pdf?symbol=en/A/RES/71/313 (accessed on 20 January 2022).

6. Klikocka, H.; Zakrzewska, A.; Chojnacki, P. Characteristics of Models of Farms in the European Union. Sustainability 2021, 13, 4772. [CrossRef]

7. Statistik Austria. Landwirtschaftliche Gesamtrechnung (LGR): Österreichergebnisse 2020; Statistik Austria: Vienna, Austria, 2021.

8. Michalek, J.; Ciaian, P.; Pokrivcak, J. The impact of producer organizations on farm performance: The case study of large farms from Slovakia. Food Policy 2018, 75, 80-92. [CrossRef]

9. Duvaleix-Treguer, S. Producer Organisations in the Meat Sector. In The Contribution of Producer Organisations to an Efficient Agri-Food Supply Chain; European Commission: Bruxelles, Belgium, 2018; Available online: https:/ /hal.archives-ouvertes.fr/hal01923028/document (accessed on 14 January 2022).

10. Javornicky, M.; Macken-Walsch, A.; Naugthon, A. Emerging Beef Producer Organisations (POs) in the Irish Beef Sector: An Analysis of Media Coverage in the Context of Nationwide Beef Producer Protests. Sustainability 2021, 13, 1489. [CrossRef]

11. OECD. Market Concentration. 2022. Available online: https://www.oecd.org/competition/market-concentration.htm (accessed on 13 January 2022).

12. Krejčí, I.; Moulis, P.; Pitrová, J.; Tichá, I.; Pilař, L.; Rydval, J. Traps and Opportunities of Czech Small-Scale Beef Cattle Farming. Sustainability 2019, 11, 4245. [CrossRef]

13. Lutz, J.; Smetschka, B.; Grima, N. Farmer Cooperation as a Means for Creating Local Food Systems-Potentials and Challenges. Sustainability 2017, 9, 925. [CrossRef]

14. Peleckis, K. Determining the Level of Market Concentration in the Construction Sector-Case of Application of the HHI Index. Sustainability 2022, 14, 779. [CrossRef]

15. Di Foggia, G.; Beccarello, M. Market Structure of Urban Waste Treatment and Disposal: Empirical Evidence from the Italian Industry. Sustainability 2021, 13, 7412. [CrossRef]

16. Nes, K.; Colen, L.; Ciaian, P. Market Power in Food Industry in Selected EU Member States; Publications Office of the European Union: Luxembourg, 2021. Available online: https:/ / data.europa.eu/doi/10.2760/63613 (accessed on 14 January 2022).

17. Wieser, R.; Wüger, M.; Aiginger, K. Marktmacht im Einzelhandel (Market Power in Retailing). 1999. Available online: https: / / www.wifo.ac.at/jart/prj3/wifo / main.jart?content-id=1454619331110\&publikation_id=8374\&detail-view=yes (accessed on 19 November 2020). 
18. Salhofer, K.; Tribl, C.; Sinabell, F. Market power in Austrian food retailing: The case of milk products. Empirica 2011, 39, 109-122. [CrossRef]

19. Jumah, A. The Long Run, Market Power and Retail Pricing. Empir. Econ. 2004, 29, 605-620. [CrossRef]

20. Appelbaum, E. The estimation of the degree of oligopoly power. J. Econom. 1982, 19, 287-299. [CrossRef]

21. Bresnahan, T.F. Empirical studies of industries with market power. In Handbook of Industrial Organization; Elsevier: Amsterdam, The Netherlands, 1989; Volume 2, pp. 1011-1057. [CrossRef]

22. Azzam, A.; Andersson, H. Measuring Price Effects of Concentration in Mixed Oligopoly: An Application to the Swedish Beef-Slaughter Industry. J. Ind. Compet. Trade 2008, 8, 21-31. [CrossRef]

23. Zheng, X.; Vukina, T. Do Alternative Marketing Arrangements Increase Pork Packers' Market Power? Am. J. Agric. Econ. 2009, 91, 250-263. [CrossRef]

24. Boyer, C.N.; Brorsen, B.W. Changes in Beef Packers' Market Power after the Livestock Mandatory Price Reporting Act: An Agent-Based Auction. Am. J. Agric. Econ. 2013, 95, 859-876. [CrossRef]

25. Chung, C.; Park, S.; Lee, J. Estimating Bilateral Market Power of Processors and Retailers in the U.S. Beef Industry. Agribusiness 2018, 34, 771-792. [CrossRef]

26. Quagrainie, K. Testing for Processor Market Power in the Markets for Cattle and Hogs in Canada. Can. J. Agric. Econ. 2003, 51, 397-411. [CrossRef]

27. Reed, M.R.; Saghaian, S.H. Measuring the Intensity of Competition in the Japanese Beef Market. J. Agric. Appl. Econ. 2004, 36, 113-121. [CrossRef]

28. Assefa, T.T.; Meuwissen, M.P.M.; Gardebroek, C.; Oude Lansink, A.G.J.M. Price and Volatility Transmission and Market Power in the German Fresh Pork Supply Chain. J. Agric. Econ. 2017, 68, 861-880. [CrossRef]

29. Lan, H.; Wang, X. Estimating Market Power in the Chinese Pork-Packing Industry: A Structural Approach. China Agric. Econ. Rev. 2020, 12, 57-70. [CrossRef]

30. OECD. Supermarkets and the Meat Supply Chain: The Economic Impact of Food Retail on Farmers, Processors and Consumers; OECD Publishing: Paris, France, 2006. [CrossRef]

31. Porter, M.E. How Competitive Forces Shape Strategy; Harvard Business Review: Brighton, MA, USA, 1979; Volume 57, pp. 137-145.

32. de Roest, K.; Ferrari, P.; Knickel, K. Specialisation and economies of scale or diversification and economies of scope? Assessing different agricultural development pathways. J. Rural Stud. 2018, 59, 222-231. [CrossRef]

33. McCorriston, S. Why should imperfect competition matter to agricultural economists? Eur. Rev. Agric. Econ. 2002, 29, 349-371. [CrossRef]

34. Goerres, A.; Prinzen, K. Using mixed methods for the analysis of individuals: A review of necessary and sufficient conditions and an application to welfare state attitudes. Qual. Quant. 2012, 46, 415-450. [CrossRef]

35. Lenger, A.; Kruse, J. Qualitative Forschungsmethoden in der deutschen Volkswirtschaftslehre. In Die Innenwelt der Ökonomie: Wissen, Macht und Performativität in der Wirtschaftswissenschaft; Maeße, J., Pahl, H., Sparsam, J., Eds.; Springer Fachmedien: Wiesbaden, Germany, 2017; pp. 107-134. Available online: https:/ / doi.org/10.1007/978-3-658-10428-3_5 (accessed on 15 November 2020).

36. Schlippenbach, V.; Pavel, F. Konzentration im Lebensmitteleinzelhandel: Hersteller Sitzen am Kürzeren Hebel; DIW Wochenbericht: Berlin, Germany, 2011; Volume 13, pp. 2-9. Available online: https://www.diw.de/de/diw_01.c.455413.de/publikationen/ wochenberichte/2011_13_1/konzentration_im_lebensmitteleinzelhandel_hersteller_sitzen_am_kuerzeren_hebel.html (accessed on 15 November 2020).

37. Akimowicz, M.; Vyn, R.J.; Cummings, H.; Landman, K. An introduction to mixed methods research in agricultural economics: The example of farm investment in Ontario's Greenbelt, Canada. J. Rural Stud. 2018, 61, 162-174. [CrossRef]

38. Jefferson, T.; Austen, S.; Sharp, R.; Ong, R.; Lewin, G.; Adams, V. Mixed-methods research: What's in it for economists? Econ. Labour Relat. Rev. 2014, 25, 290-305. [CrossRef]

39. Perloff, J.M.; Karp, L.S.; Golan, A. Estimating Market Power and Strategies, 1st ed.; Cambridge University Press: Cambridge, UK, 2007.

40. U.S. Department of Justice. Horizontal Merger Guidelines (08/19/2010). 2015. Available online: https:/ /www.justice.gov/atr/ horizontal-merger-guidelines-08192010 (accessed on 12 September 2021).

41. Statistik Austria. Erhebung des Rinderbestands (Vollerhebung). 2011. Available online: https://www.statistik.at/wcm/ idc/idcplg?IdcService=GET_PDF_FILE\&RevisionSelectionMethod=LatestReleased\&dDocName=053305 (accessed on 9 December 2021).

42. Statistik Austria. Schweinezählung (Stichprobe) 2000-2011. 2011. Available online: https://www.statistik.at/wcm/idc/idcplg? IdcService=GET_PDF_FILE\&RevisionSelectionMethod=LatestReleased\&dDocName=053306 (accessed on 9 December 2021).

43. Fałkowski, J.; Ciaian, P. Factors Supporting the Development of Producer Organizations and Their Impacts in the Light of Ongoing Changes in Food Supply Chains. 2016. Available online: https://op.europa.eu/en/publication-detail/-/publication/ ef388b8d-2171-11e6-86d0-01aa75ed71a1/language-en. (accessed on 9 December 2021).

44. Agricultural Markets Task Force. Improving Market Outcomes-Enhancing the Position of Farmers in the Supply Chain; European Commission: Brussels, Belgium, 2016.

45. Velázquez, B.; Buffaria, B.; European Commission. About Farmers' Bargaining Power within the New CAP. Agric. Food Econ. 2017, 5, 16. [CrossRef]

46. Deconinck, K. Concentration and Market Power in the Food Chain; OECD Publishing: Paris, France, 2021; p. 151. [CrossRef] 
47. Schütz, K.; Klüsener, K.; Mergenthaler, M. Chancen und Risiken einer Marktdifferenzierung durch innovative Lieferbeziehungen für mehr Tierwohl und Nachhaltigkeit in der landwirtschaftlichen Tierhaltung in NRW aus Sicht von Branchenvertreter:innen. Ber. Landwirtsch. 2021, 99, 1-37.

48. Qualitative Content Analysis: Demarcation, Varieties, Developments. Available online: https://www.qualitative-research.net/ index.php/fqs/article/view/3343 (accessed on 10 May 2021).

49. Statistik Austria. Leistungs- und strukturstatistik 2018-Hauptergebnisse. 2018. Available online: https://www.statistik. at/web_de/statistiken/wirtschaft/produktion_und_bauwesen/leistungs_und_strukturdaten/index.html (accessed on 16 December 2020).

50. AMA (Agrarmarkt Austria). RollAMA Household Panel (KeyQuest, 2018) Marktinformation Vieh und Fleisch-Konsumverhalten; Eigenverlag: Wien, Austria, 2018.

51. European Commission. EU Farm Economics Overview FADN 2018; Directorate General for Agriculture and Rural Development: Brussels, Belgium, 2021.

52. BMLRT (Bundesministerium für Landwirtschaft, Regionen und Tourismus). Grüner Bericht 2021 (Green Report 2021 ). 2021. Available online: https://gruenerbericht.at/cm4/jdownload/download/2-gr-bericht-terreich/2393-gb2021 (accessed on 10 December 2021).

53. Gilbert, C.L.; Morgan, C.W. Food price volatility. Philos. Trans. R. Soc. B Biol. Sci. 2010, 365, 3023-3034. [CrossRef]

54. Bellemare, M.F. Rising Food Prices, Food Price Volatility, and Social Unrest. Am. J. Agric. Econ. 2015, 97, 1-21. [CrossRef]

55. Bellarby, J.; Tirado, R.; Leip, A.; Weiss, F.; Lesschen, J.P.; Smith, P. Livestock greenhouse gas emissions and mitigation potential in Europe. Glob. Chang. Biol. 2013, 19, 3-18. [CrossRef]

56. Chai, B.C.; van der Voort, J.R.; Grofelnik, K.; Eliasdottir, H.G.; Klöss, I.; Perez-Cueto, F.J.A. Which Diet Has the Least Environmental Impact on Our Planet? A Systematic Review of Vegan, Vegetarian and Omnivorous Diets. Sustainability 2019, 11, 4110. [CrossRef] 